\title{
Black decorative anticorrosion coatings obtained on AA2024 alloy by plasma-electrolytic treatment and inhibition
}

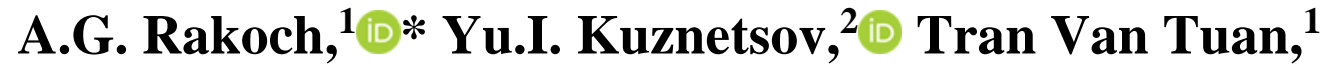 \\ Z.V. Khabibullina, ${ }^{1}$ A.A. Gladkova, ${ }^{1}$ A.A. Chirkunov ${ }^{2} \mathbb{D}$ \\ and A.M. Semiletov ${ }^{2} \mathbb{D}$
}

${ }^{1}$ Department of Metal Protection and Surface Treatment, National University of Science and Technology "MISiS”, Leninsky pr. 4, 119049 Moscow, Russian Federation

${ }^{2}$ A.N. Frumkin Institute of Physical Chemistry and Electrochemistry, Russian Academy

of Sciences, Leninsky pr. 31, 119071 Moscow, Russian Federation

*E-mail: rakoch@mail.ru

\begin{abstract}
This research work is concerned with developing a model of black anticorrosion coatings growth during plasma electrolytic treatment of a widely used industrial alloy AA2024 and investigation of corrosion inhibitor use efficiency depending on a coating thickness. The inhibitor used in this study is an equimolar composition of sodium oleoyl sarcosinate and sodium flufenamate. Assuring that addition of $1.5 \mathrm{~g} / \mathrm{l} \mathrm{Co}(\mathrm{OH})_{3}$ into an alkaline aqueous solution ( $\mathrm{pH} \sim 12.6$ ), containing $5 \mathrm{~g} / \mathrm{l}$ of technical water glass, leads to the formation of visually black coatings with higher anticorrosion properties, the following assumptions were made: 1) the visual black color of a coating is mainly provided with the existence of $\mathrm{CoO}$ and $\mathrm{Co}_{3} \mathrm{O}_{4}$ oxides; 2) the increase in the anticorrosive properties of the coatings is caused by the filling of many open pores in the coatings with cobalt orthosilicate which is more fusible than aluminum oxide. Major filling of the pores with the double oxide takes place on the surface of a forming inner layer prior to its intensive growth under the outer layers of the coatings. As a result, a coating with a thickness of $17 \mu \mathrm{m}$ has higher anticorrosion properties than the ones with thicknesses of 38 and $70 \mu \mathrm{m}$. Results of energy dispersive X-ray spectroscopy and review of the data given in the published scientific works confirm the possibility of the abovementioned hypothesis. The efficiency of the corrosion inhibitor is also higher for a coating with a thinner inner layer, when it has already started to be formed under porous outer layers of the coating. The black coating with an average thickness of $17 \mu \mathrm{m}$, loaded with the mixed inhibitor, shows the maximum decrease (by approximately 467.4 times) in the corrosion current density, i.e., the greatest protection of AA2024 alloy against corrosion.
\end{abstract}

Keywords: aluminum alloy, plasma electrolytic oxidation, corrosion protection, corrosion inhibitor.

Received: March 18, 2021. Published: April 8, 2021

doi: $\underline{10.17675 / 2305-6894-2021-10-2-5}$ 


\section{Introduction}

AA2024 alloy is widely used in aerospace industry, for producing frames of different items, weapon components and consumer goods on account of unique combination of high strength (up to $600 \mathrm{MPa}$ ) and low density (approximately $2.8 \mathrm{~g} / \mathrm{cm}^{3}$ ). However, due to low corrosion and wear resistances, protective coatings are applied on items made of this alloy. Plasma electrolytic treatment is one of the most widely used methods for modification of items surface made of aluminum alloys. Some scientists call this method plasma electrolytic oxidation (PEO), some of them-microarc oxidation (MAO). However, during ignition of anodic plasma microdischarges coatings are growing not just a result of metal substrate oxidation but also electrolysis and/or electrophoresis processes and plasma thermochemical treatment. It means that different compounds, mainly oxides formed by electrolyte components can be found in the obtained coatings. Absence of the latter processes does not allow to synthesize decorative coatings with different colors by use of this method. Colors of PET coatings often depend on principal alloying elements of alloys.

For the first time this method was used to synthesize coatings, containing components of electrolyte and metal substrate, on light constructional alloys in 1956-1965 [1-5]. Taking into account that ignition of plasma microdischarges plays an essential role in processing this method, and that this process takes place in case of conducting materials existence in an electrolyte, a more proper name for this method is plasma electrolytic treatment (PET).

Up to date, various process parameters have been developed for PET of aluminum alloys. The process parameters to obtain coatings with different colors on these alloys have been already established empirically by researchers [6-13]. However, the following disadvantages take place: 1) the electrolytes contain a lot of complex compounds which are hard controllable for large-scale production and, as a result, it is almost impossible to organize operational stability and obtain coatings of high quality; 2) the electrolytes are also harmful for ecology, containing toxic compounds, including bichromates, molybdates, alkali metal ferrocyanides. Moreover, the decorative coatings, synthesized by developed methods on aluminum alloys as usual do not have high anticorrosive properties. Furthermore, application of corrosion inhibitors to improve corrosion resistance of decorative PET coatings has not been studied well yet.

It was established that addition of cobalt salts into electrolytes leads to increasing corrosion and wear resistances of PET coatings synthesized on light constructional alloys [14-16]. For example, addition of $0.8 \mathrm{~g} / \mathrm{l} \mathrm{CoSO}$ to an aqueous solution of $12 \mathrm{~g} / \mathrm{N} \mathrm{Na}_{2} \mathrm{SiO}_{3}$, $1 \mathrm{~g} / \mathrm{l} \mathrm{NaF}, 2 \mathrm{~g} / \mathrm{l} \mathrm{C}_{4} \mathrm{H}_{4} \mathrm{O}_{6} \mathrm{KNa}, 3 \mathrm{~g} / \mathrm{l} \mathrm{NaOH}$ results in significant improvement of microhardness and anticorrosion properties of PEO coatings obtained on ZL108 aluminum alloy [16]. However, the researchers proposed the wrong mechanism of cobalt sulfate influence on properties of the synthesized coatings. They did not perform direct corrosion tests and did not mention colors of the coatings synthesized after PET in the multicomponent electrolyte. 
Thus, the main aims of the present study are:

1) to find out the mechanism of the black decorative anticorrosive coatings growth on widely used aluminum alloy AA2024 during its PET;

2) to develop a method to increase corrosion resistance of coatings by their impregnation with mixed corrosion inhibitor, which is an equimolar composition of carboxylate compounds: sodium oleyl sarcosinate (SOS) and sodium flufenamate (SFF).

\section{Experimental}

\section{PET of AA2024 aluminum alloy}

PET processes were conducted by use of the capacity-based equipment, detailed description of which is given in [17]. An alternating current was passed between the electrodes with a specified current density of $15 \mathrm{~A} / \mathrm{dm}^{2}$, which is supposed to be one of the most used current densities for producing wear-resistant coatings on aluminum alloys [18-20]. The current was stabilized by its average rectified value.

To synthesize corrosion resistant coatings mainly consisting of various aluminum oxide phases PET process was performed on specimens $(30 \times 20 \times 3 \mathrm{~mm})$ of AA2024 aluminum alloy (Table 1) in alkaline aqueous solution ( $\mathrm{pH} \sim 12.6)$, containing $5 \mathrm{~g} / \mathrm{l}$ of technical water glass $\left(\mathrm{NaO} \cdot 2.9 \mathrm{SiO}_{2} \cdot 18 \mathrm{H}_{2} \mathrm{O}\right)$. Hereafter this electrolyte will be called as a base electrolyte. To obtain decorative black coatings $\mathrm{Co}(\mathrm{OH})_{3}(1.5 \mathrm{~g} / \mathrm{l})$ was added into the base electrolyte. The total volume of the electrolytes was constantly adjusted to $5 \mathrm{~L}$.

Table 1. Concentration (wt.\%) of main alloying elements in AA2024 alloy.

\begin{tabular}{cccccccc}
\hline $\mathbf{C u}$ & $\mathbf{M n}$ & $\mathbf{M g}$ & $\mathbf{S i}$ & $\mathbf{F e}$ & $\mathbf{C r}$ & $\mathbf{Z n}$ & $\mathbf{T i}$ \\
\hline 3.90 & 0.60 & 1.60 & 0.50 & 0.50 & 0.10 & 0.25 & 0.15 \\
\hline
\end{tabular}

The $\mathrm{pH}$ of the electrolytes was measured using " $\mathrm{pH} 211$ " $\mathrm{pH}-$ meter (HANNA Instruments) at room temperature.

Investigation of the thickness, structure and elemental composition of PET coatings

The thicknesses of PET coatings were estimated at 15 randomly selected locations using a Fischer Dualscope FNP10 coating thickness gauge and the average values were calculated. Prior to measurements the device was calibrated using uncoated substrate material and calibration samples.

The micrographs of the PET coatings cross-section were examined by scanning electron microscopy using a Tescan VEGA3 SB, and the elemental composition at different places of the coatings were determined using energy dispersive X-ray spectroscopy (EDX).

The phase composition was investigated using a Rigaku Ultima IV X-ray diffractometer with monochromated Co K $\alpha$-radiation. 


\section{Selection of corrosion inhibitor}

In the past, the compounds containing chromates were widely used to increase protection properties of aluminum alloys. However, their application is limited because they are environmentally harmful. Non-toxic organic inhibitors could partially remove chromate compounds [21, 22].

Carboxylic acids and their salts which, besides good anticorrosion properties, are nontoxic and less harmful for ecology, approved themselves as an effective inhibitor for aluminum alloys $[23,24]$. It was shown in $[25,26]$ that the mixed composition of IFKhAN 25 increases anticorrosive properties of oxidized aluminum alloys in solutions containing chlorine ions.

Moreover, in [27] properties of different well-known corrosion inhibitors, applied on AA2024 alloy, were investigated. The most effective inhibitor for protection from atmospheric corrosion was a composition based on equimolar mixture of SOS $\left[\mathrm{CH}_{3}\left(\mathrm{CH}_{2}\right)_{7} \mathrm{CH}=\mathrm{CH}\left(\mathrm{CH}_{2}\right)_{7} \mathrm{CON}\left(\mathrm{CH}_{3}\right) \mathrm{CH}_{2} \mathrm{COONa}\right]$ and $\left.\mathrm{SFF}\left[\left(\mathrm{CF}_{3}\right) \mathrm{C}_{6} \mathrm{H}_{4} \mathrm{NH}\right] \mathrm{C}_{6} \mathrm{H}_{4} \mathrm{COONa}\right]$. Therefore, having aimed to evaluate more detailed information about effectiveness of this inhibitor for corrosion protection, it was chosen for impregnating PET coatings, synthesized on AA2024 alloy.

\section{Corrosion testing and electrochemical measurements}

The corrosion testing of PET coatings was carried out by immersing them in $3 \mathrm{wt} \% \mathrm{NaCl}$ aqueous solution for $24 \mathrm{~h}$.

The electrochemical measurements were performed to confirm the corrosion testing results. The polarization curves of uncoated and PET coated samples were obtained in a 3 wt.\% $\mathrm{NaCl}$ solution, using a three-electrode configuration, with an $\mathrm{Ag} / \mathrm{AgCl}$ reference electrode and a platinum-coated titanium counter electrode. To perform the measurements, IPC-Pro 3 A digital potentiostat was used and run by the software IPC-2000. Anodic polarization is performed in a potentiodynamic mode with a potential scan rate of $1 \mathrm{mV} / \mathrm{s}$. The initial polarization potentials were more negative (at least for $200 \mathrm{mV}$ ) than the values of samples steady state potentials. The values of the corrosion current density were calculated by the Stern-Geary method [59].

\section{Results and discussion}

\section{Kinetics of PET coatings growth on AA2024 alloy}

Colors of PET coatings obtained on AA2024 alloy in the base electrolyte depend on a main alloying element and a coating thickness (Figures 1a, 1b, 1c). Initially the oxidation of a metal substrate leads to growth of a coating, with further continuation of treatment growth of the coating mainly occurs due to electrolysis of $n\left[\mathrm{Si}_{x} \mathrm{O}_{y}\right]^{m-}$ polyanions (Figure 1c).

Addition of $1.5 \mathrm{~g} / \mathrm{Co}(\mathrm{OH})_{3}$ into the base electrolyte results in formation of visually black coatings on AA2024 alloy after its PET (Figures 1d, 1e, 1f), while the kinetics of 
coatings growth and the evolution of voltages as a function of time during PET practically do not change (Figure 2).
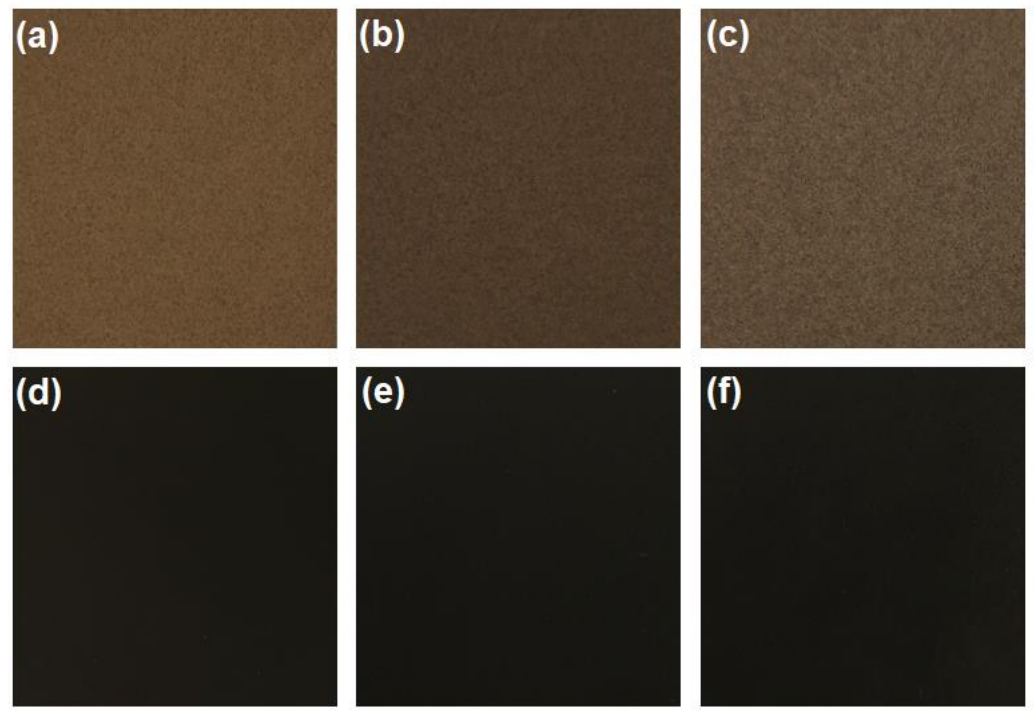

$1 \mathrm{~cm}$

Figure 1. Appearance of the samples with the coatings obtained in the base electrolyte without $(\mathrm{a}, \mathrm{b}, \mathrm{c})$ and with addition into it $1.5 \mathrm{~g} / \mathrm{l} \mathrm{Co}(\mathrm{OH})_{3}(\mathrm{~d}, \mathrm{e}, \mathrm{f})$; average coating thicknesses are $17 \mu \mathrm{m}$ (1a, 1d), $38 \mu \mathrm{m}(1 \mathrm{~b}, 1 \mathrm{e})$ and $70 \mu \mathrm{m}(1 \mathrm{c}, 1 \mathrm{f})$.
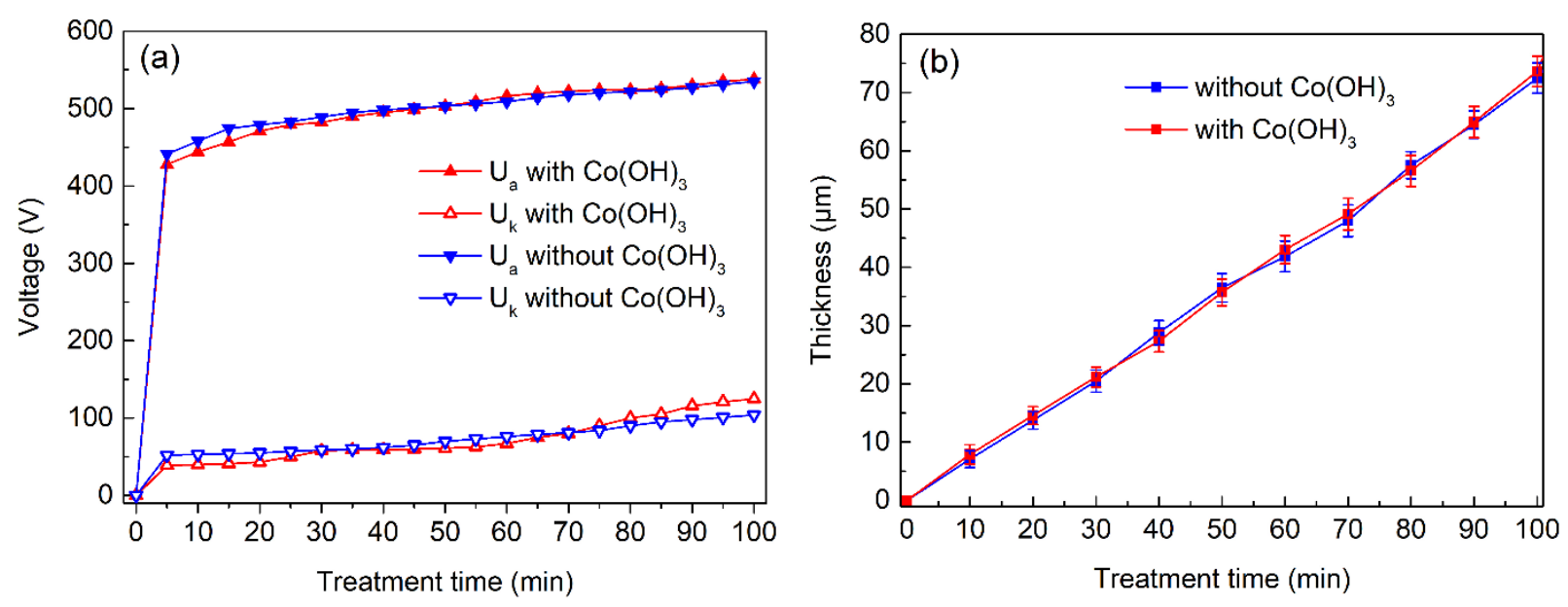

Figure 2. Kinetic of PET coatings formation (a) and evolution of anodic and cathodic voltages (b) as function of a time during treatment of AA2024 alloy in the base electrolyte without and with addition of $1.5 \mathrm{~g} / \mathrm{l} \mathrm{Co}(\mathrm{OH})_{3}$.

PET coatings synthesized in the base electrolyte without and with addition of $1.5 \mathrm{~g} / \mathrm{l}$ $\mathrm{Co}(\mathrm{OH})_{3}$ are two-layered (Figure 3). In the beginning of PET processes the average growth rate of an outer layer is higher than the rate of inner layer formation (Figures $3 \mathrm{a}, 3 \mathrm{~b}$ ). Moreover, horizontal pores are also detected between these two layers. However, with further continuation of treatment the rate of inner layer formation is becoming higher than that for the coating outer layer (Figures 3c, 3d, 3e, 3f). 

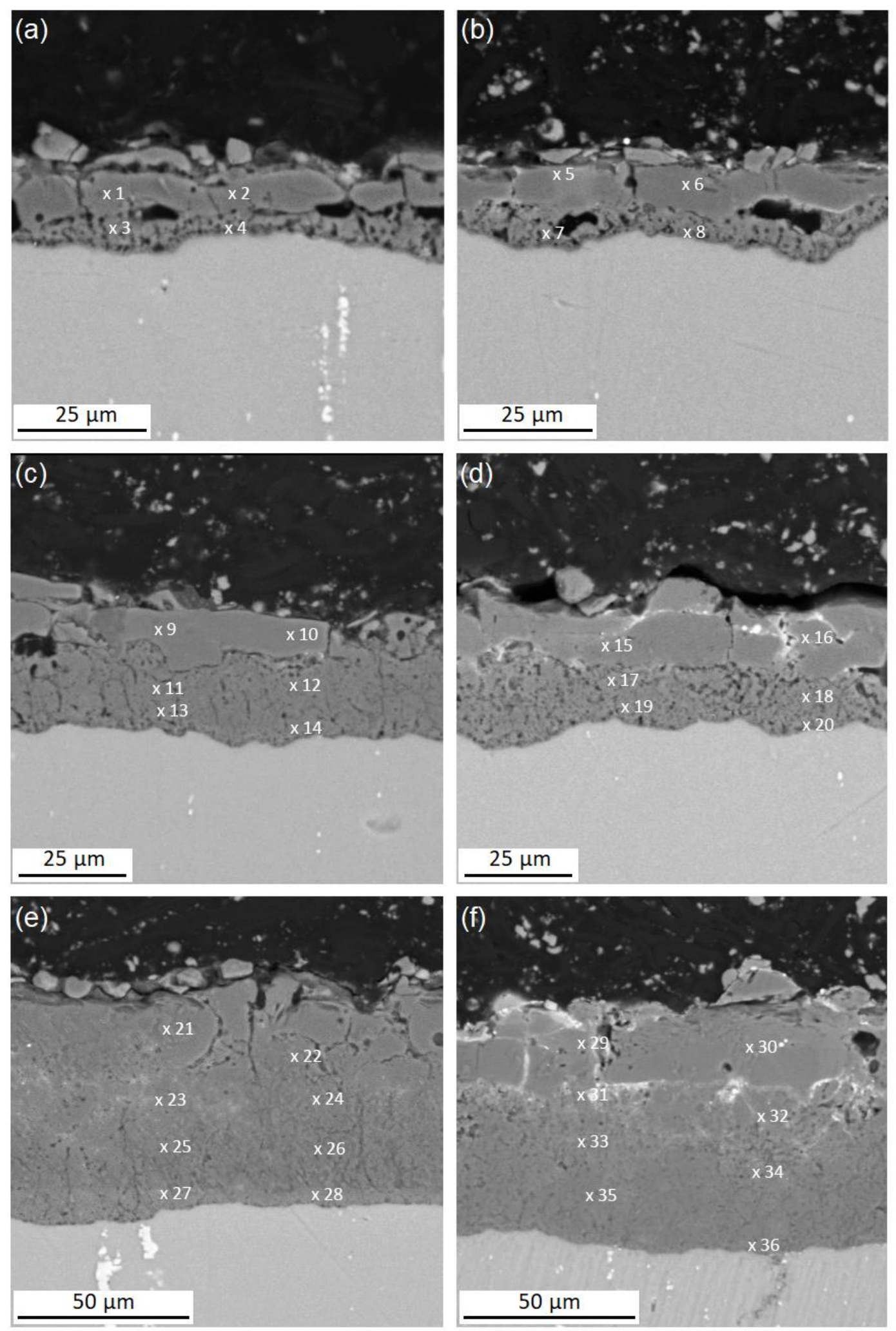

Figure 3. Cross-sectional SEM micrographs of coatings synthesized on AA2024 alloy in the base electrolyte without (a,c,e) and with addition into it of $1.5 \mathrm{~g} / \mathrm{l} \mathrm{Co}(\mathrm{OH})_{3}(\mathrm{~b}, \mathrm{~d}, \mathrm{f})$; average coating thicknesses are $17 \mu \mathrm{m}(3 \mathrm{a}, 3 \mathrm{~b}), 38 \mu \mathrm{m}(3 \mathrm{c}, 3 \mathrm{~d})$, and $70 \mu \mathrm{m}(3 \mathrm{e}, 3 \mathrm{f})$. 


\section{Phase and elemental composition of PET coatings}

Based on XRD results, these coatings mainly consist of $\gamma-$ and $\alpha-\mathrm{Al}_{2} \mathrm{O}_{3}$ phases (Figure 4).
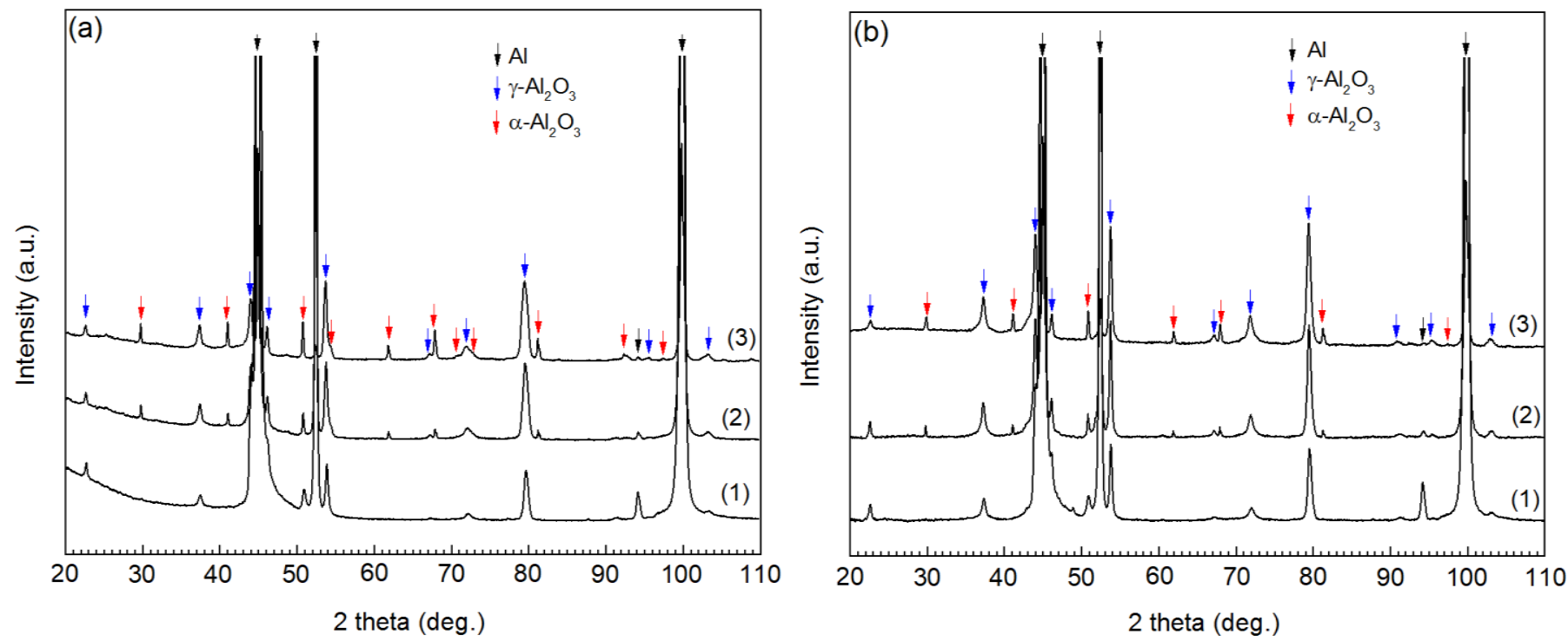

Figure 4. XRD patterns of PET coatings synthesized on AA2024 alloy in the base electrolyte without (a) and with addition into it $1.5 \mathrm{~g} / \mathrm{l} \mathrm{Co}(\mathrm{OH})_{3}$ (b); average coating thicknesses are $17 \mu \mathrm{m}(1), 38 \mu \mathrm{m}(2)$, and $70 \mu \mathrm{m}$ (3).

However, these results do not show which compounds result in a black color of the coatings, obtained after PET of AA2024 alloy in the base electrolyte with addition of $1.5 \mathrm{~g} / \mathrm{l}$ $\mathrm{Co}(\mathrm{OH})_{3}$. Based on the results of elemental composition analysis, compounds containing Co are detected in the black coatings (Figure 3, Table 2).

Table 2. Elemental composition (wt.\%) of PET coatings (locations of analysis according to Figure 3).

\begin{tabular}{|c|c|c|c|c|c|c|c|c|c|c|c|c|c|c|}
\hline \multirow{3}{*}{$\begin{array}{c}\text { Coating } \\
\text { thickness } \\
(\mu \mathrm{m})\end{array}$} & \multicolumn{7}{|c|}{ Without addition of $\mathrm{Co}(\mathrm{OH})_{3}$} & \multicolumn{7}{|c|}{ With addition of $\mathrm{Co}(\mathrm{OH})_{3}$} \\
\hline & \multirow{2}{*}{ Point } & \multicolumn{6}{|c|}{ Elemental composition (wt.\%) } & \multirow{2}{*}{ Point } & \multicolumn{6}{|c|}{ Elemental composition (wt.\%) } \\
\hline & & Al & $\mathbf{O}$ & $\mathbf{S i}$ & Co & $\mathbf{C u}$ & Mg & & Al & $\mathbf{O}$ & $\mathbf{S i}$ & Co & $\mathbf{C u}$ & Mg \\
\hline \multirow{4}{*}{17} & 1 & 48.7 & 47.0 & 3.0 & - & 0.6 & 0.7 & 5 & 49.0 & 46.1 & 1.5 & 2.8 & - & 0.6 \\
\hline & 2 & 48.8 & 47.2 & 3.1 & - & 0.5 & 0.4 & 6 & 49.5 & 47.3 & 1.0 & 1.7 & 0.5 & - \\
\hline & 3 & 48.9 & 47.1 & 2.6 & - & 0.7 & 0.7 & 7 & 48.3 & 45.7 & 2.1 & 2.4 & 0.9 & 0.6 \\
\hline & 4 & 48.7 & 47.8 & 1.8 & - & 1.1 & 0.6 & 8 & 48.6 & 46.1 & 1.6 & 1.8 & 1.2 & 0.7 \\
\hline
\end{tabular}




\begin{tabular}{|c|c|c|c|c|c|c|c|c|c|c|c|c|c|c|}
\hline \multirow{3}{*}{$\begin{array}{c}\text { Coating } \\
\text { thickness } \\
(\mu \mathrm{m})\end{array}$} & \multicolumn{7}{|c|}{ Without addition of $\mathrm{Co}(\mathrm{OH})_{3}$} & \multicolumn{7}{|c|}{ With addition of $\mathrm{Co}(\mathrm{OH})_{3}$} \\
\hline & \multirow{2}{*}{ Point } & \multicolumn{6}{|c|}{ Elemental composition (wt.\%) } & \multirow{2}{*}{ Point } & \multicolumn{6}{|c|}{ Elemental composition (wt.\%) } \\
\hline & & Al & $\mathbf{O}$ & $\mathbf{S i}$ & Co & $\mathrm{Cu}$ & Mg & & Al & $\mathbf{O}$ & $\mathbf{S i}$ & Co & $\mathrm{Cu}$ & Mg \\
\hline \multirow{6}{*}{38} & 9 & 51.4 & 46.4 & 1.7 & - & - & 0.5 & 15 & 51.9 & 45.9 & 0.7 & 0.9 & - & 0.6 \\
\hline & 10 & 49.9 & 46.7 & 2.0 & - & 0.6 & 0.8 & 16 & 47.8 & 46.1 & 2.8 & 2.2 & 0.5 & 0.6 \\
\hline & 11 & 51.6 & 46.9 & - & - & 0.8 & 0.7 & 17 & 50.1 & 46.7 & 0.6 & 1.3 & 0.7 & 0.6 \\
\hline & 12 & 51.2 & 46.5 & 0.8 & - & 1.0 & 0.5 & 18 & 51.5 & 45.4 & 0.7 & 0.5 & 1.2 & 0.7 \\
\hline & 13 & 53.3 & 45.0 & - & - & 1.1 & 0.6 & 19 & 51.7 & 45.8 & 0.4 & - & 1.6 & 0.5 \\
\hline & 14 & 53.2 & 44.6 & - & - & 1.4 & 0.8 & 20 & 51.8 & 45.5 & - & - & 1.8 & 0.9 \\
\hline \multirow{8}{*}{70} & 21 & 53.9 & 44.7 & 1.0 & - & - & 0.4 & 29 & 45.4 & 40.3 & 2.8 & 9.6 & 1.2 & 0.7 \\
\hline & 22 & 52.9 & 44.2 & 0.7 & - & 1.5 & 0.7 & 30 & 44.3 & 40.5 & 2.9 & 10.8 & 0.7 & 0.8 \\
\hline & 23 & 51.1 & 45.8 & 0.5 & - & 1.6 & 1.0 & 31 & 50.2 & 44.9 & 1.7 & 2.4 & - & 0.8 \\
\hline & 24 & 52.9 & 44.6 & 1.1 & - & 0.8 & 0.6 & 32 & 45.3 & 44.0 & 3.4 & 4.2 & 2.1 & 1.0 \\
\hline & 25 & 50.6 & 46.1 & 1.2 & - & 1.4 & 0.7 & 33 & 48.4 & 44.5 & 2.5 & 1.2 & 2.6 & 0.8 \\
\hline & 26 & 51.2 & 45.9 & 0.9 & - & 1.2 & 0.8 & 34 & 49.7 & 44.4 & 0.7 & 0.8 & 3.2 & 1.2 \\
\hline & 27 & 51.4 & 46.8 & 0.5 & - & 0.9 & 0.4 & 35 & 51.1 & 45.3 & - & - & 2.5 & 1.1 \\
\hline & 28 & 52.6 & 44.8 & - & - & 1.9 & 0.7 & 36 & 52.3 & 45.9 & - & - & 1.2 & 0.6 \\
\hline
\end{tabular}

Probably, a black color is a result of the following reasons:

1) the presence of $\mathrm{CoO}$ and $\mathrm{Co}_{3} \mathrm{O}_{4}$ oxides which have a dark-green (close to black) and greyblack colors respectively [29]. However, due to low concentration of these oxides in the coatings they cannot be detected by XRD analysis. Only using X-ray photoelectron spectroscopy [16] could detect them besides aluminum oxides in the coating, synthesized on ZL108 aluminum alloy after its PET;

2) the presence of cobalt and copper oxides. It should be mentioned that $\mathrm{CuO}$ results in a black color of the coatings inner layer, formed in the base electrolyte [18, 23, 30]. Despite copper oxides were not detected by XRD analysis (Figure 4), result of the elemental composition analysis indicates that the coatings also contain compounds of copper (Figure 3, Table 2).

A growth mechanism of two-layered PET coatings

It was established that prior to PET processes in alkaline silicate electrolytes the anodizing and electrolysis of anions and/or $n\left[\mathrm{Si}_{x} \mathrm{O}_{y}\right]^{m-}$ polyanions on the aluminum alloys take place, leading to formation of a porous layer [18, 20, 31-34]. Partial closure of the coating surface 
with the gas-vapor phase and its formation in the coating pores result in intensive and fast increase of the anodic voltage up to the values, exceeding the breakdown potential of the gas-vapor phase. All processes like oxidation of a metal substrate, electrolysis of ions and polyanions, electrophoresis of particles (dipoles) on a working electrode and plasma thermochemical treatment occur.

Black color of the coating also confirms that electrolysis and electrophoresis processes during PET of aluminum alloy take place (Figures 1d, 1e, 1f). Local etching of a metal substrate and of an anodic layer under initial layers of coating in areas adjacent to microdischarges ignition occur. The temperature in these microdischarges reaches several thousands of degrees Celsius [33,35]. Probably, the formation of small semispheric and nodular voids, generally adjacent to pores of the anodic layer, in the metal substrate takes place in the early stages of PEO processing. Ignition and blowing-out of anodic microdischarges in various places lead to formation of many small pores. Formation of horizontal pores also takes place as a result of small pores coalescence (Figures 3a, 3b). Electrolyte penetrates into them through vertical pores of a coating, and various microdischarges occur under outer layer of PET coating during anodic polarization of a working electrode. Thus, an inner layer of PET coating start to grow on the anodic layer as a result of metal substrate oxidation. The horizontal pores initially still occur above the inner layer. With further continuation of PET processing, the microdischarges, igniting under the coating outer layer, lead to oxidation of the metal substrate with and without transportation of molten particles, mainly composed of aluminum oxide, not onto the coating surface but on a surface of the inner layer.

The absence of $\mathrm{Si}$ and $\mathrm{Co}$ compounds at places adjacent to the metal substrate (Figures 3c, 3d, 3e, 3f, Table 2) indicates that the oxidation of the metal base occurs.

During ignition of microdischarges under the coating outer layers, formation of the inner layers and closure of the coating pores take place (Figure 3).

Thus, microdischarges, igniting in vertical transverse pores of a coating, mainly result in formation of the outer layers, while intensive growth of the inner layers occurs as a result of microdischarges ignition under the coating outer layers.

\section{Anticorrosion properties of PET coatings}

The corrosion tests gave the following results:

1) nine and five spots of the pitting corrosion were detected on a surface of the samples with PET coatings of 17 and $38 \mu \mathrm{m}$ thickness, synthesized in the base electrolyte, respectively;

2) no corrosion traces were found on a surface of another samples, formed on AA2024 alloy in the base electrolyte without and with addition of $1.5 \mathrm{~g} / \mathrm{C} \mathrm{Co}(\mathrm{OH})_{3}$. However, corrosion processes could take place under the coatings.

The electrochemical tests were performed to define a coating with the highest corrosion resistance: the lower corrosion current density is, the better anticorrosion properties of a coating. 
The electrochemical tests of the coatings conducted in 3 wt. \% $\mathrm{NaCl}$ aqueous solution gave the following results:

1) AA2024 alloy is in a passive state;

2) there is a high probability of the pitting corrosion due to shifting of corrosion potential toward positive values from the corrosion potential of AA2024 alloy.

However, according to the obtained data, the thickest coating (with the average coating thickness is $70 \mu \mathrm{m}$ ), synthesized in the base electrolyte, have better anticorrosion properties than the ones with average thicknesses 17, $38 \mu \mathrm{m}$ (Figure 5, Table 3). Corrosion current density of AA2024 alloy with PET coating of $70 \mu \mathrm{m}$ thickness decreases 35.8 times, while corrosion current densities of the coatings with 38 and $17 \mu \mathrm{m}$ thicknesses are lower only for 17.2 and 10.5 times, respectively.

Therefore, the thicker coating, obtained on AA2024 alloy by its PET in the base electrolyte, the better its corrosion resistance.
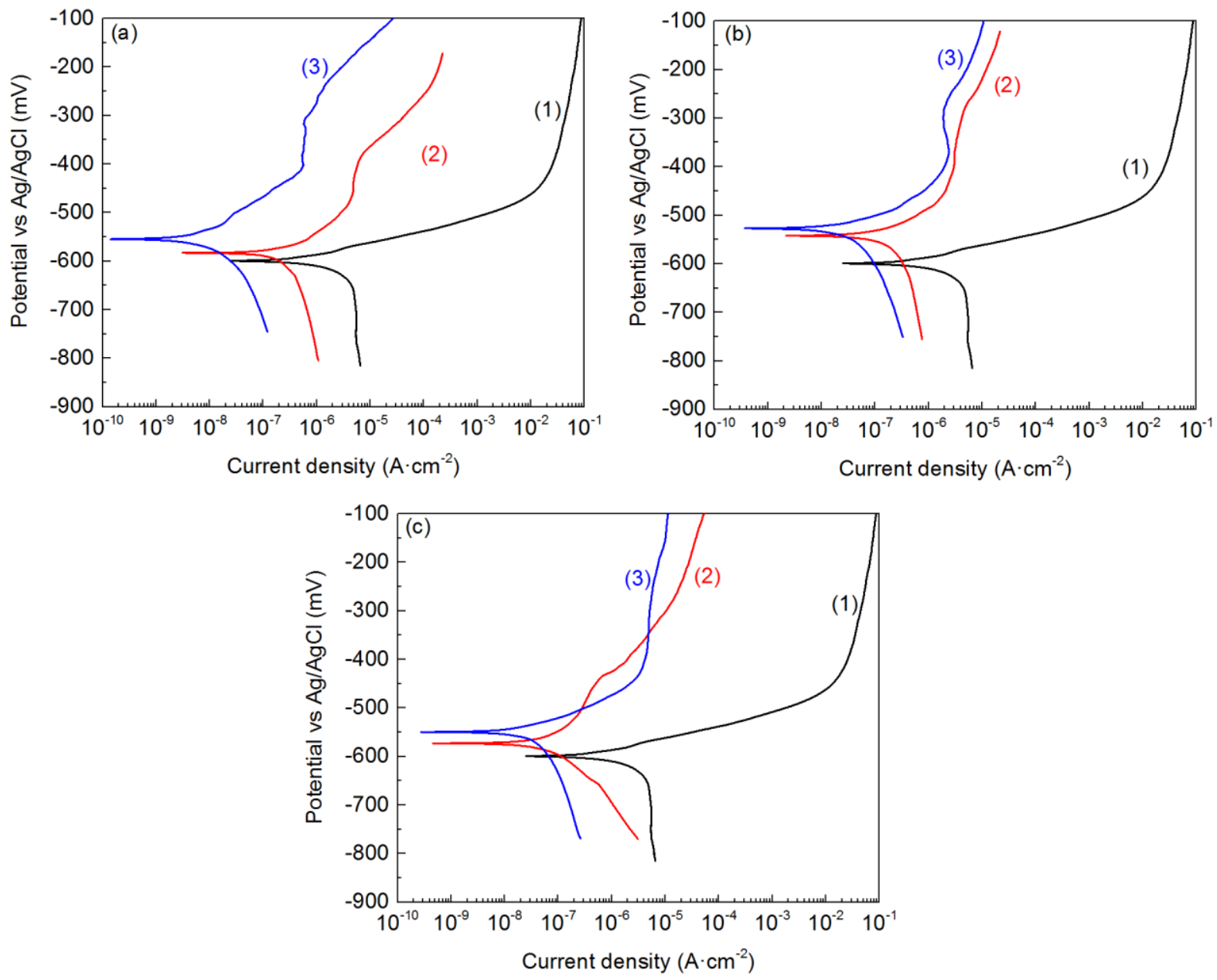

Figure 5. Potentiodynamic polarization curves for the corrosion of AA2024 alloy in 3 wt.\% $\mathrm{NaCl}$ aqueous solution without (1) and with PET coatings obtained in the base electrolyte (2) and with addition of $1.5 \mathrm{~g} / \mathrm{l} \mathrm{Co}(\mathrm{OH})_{3}(3)$; average coating thicknesses are $17 \mu \mathrm{m}(\mathrm{a})$, $38 \mu \mathrm{m}(\mathrm{b})$, and $70 \mu \mathrm{m}(\mathrm{c})$. 
Table 3. Corrosion potentials and current densities of AA2024 alloy without and with PET coatings in 3 wt. $\% \mathrm{NaCl}$ aqueous solution.

\begin{tabular}{cccc}
\hline $\begin{array}{c}\text { Coating } \\
\text { thickness, } \boldsymbol{\mu} \mathbf{m}\end{array}$ & Electrolyte & $-\boldsymbol{V}, \mathbf{m V}$ & $\boldsymbol{i , \mathbf { A } / \mathbf { c m } ^ { 2 }}$ \\
\hline 0 & - & 598 & $4.3 \times 10^{-6}$ \\
\hline \multirow{2}{*}{17} & Base & 585 & $4.1 \times 10^{-7}$ \\
\cline { 2 - 4 } & $\begin{array}{c}\text { With addition of } 1.5 \mathrm{~g} / 1 \\
\mathrm{Co}(\mathrm{OH})_{3}\end{array}$ & 551 & $2.6 \times 10^{-8}$ \\
\hline \multirow{2}{*}{38} & Base & 519 & $2.5 \times 10^{-7}$ \\
\cline { 2 - 4 } & $\begin{array}{c}\text { With addition of } 1.5 \mathrm{~g} / 1 \\
\mathrm{Co}(\mathrm{OH})_{3}\end{array}$ & 526 & $7.8 \times 10^{-8}$ \\
\hline \multirow{2}{*}{70} & Base & 573 & $1.2 \times 10^{-7}$ \\
\cline { 2 - 4 } & $\begin{array}{c}\text { With addition of } 1.5 \mathrm{~g} / 1 \\
\mathrm{Co}(\mathrm{OH})_{3}\end{array}$ & 551 & $8.5 \times 10^{-8}$ \\
\hline
\end{tabular}

Another behavior of corrosion current density was observed for black PET coatings. Corrosion current density of AA2024 alloy with coating of $17 \mu \mathrm{m}$ thickness decreases 165,4 times, while corrosion current densities of the coatings with 38 and $70 \mu \mathrm{m}$ thicknesses are lower only for 55.1 and 50.6 times, respectively. Moreover, the black coatings have higher corrosion resistance than the grey-brown ones, synthesized in the base electrolyte (Table 3). For the coatings with average thickness $17 \mu \mathrm{m}$, the corrosion current density of the black one is 15.8 times lower in comparison with the coating, obtained in the base electrolyte; for $70 \mu \mathrm{m}$ coatings, it is 1.25 times lower.

Probably, the formation of cobalt orthosilicate $\left(\mathrm{Co}_{2} \mathrm{SiO}_{4}\right)$, the melting temperature of which is much lower than that of aluminum oxide, i.e., $1415^{\circ} \mathrm{C}$ [36] and $2072^{\circ} \mathrm{C}$ [37], respectively, in black coatings result in better corrosion resistance. Cobalt orthosilicate formation is presumable due to the data of EDX analysis (Figure 6). Concentrations of Co and $\mathrm{Si}$ are high at the same places of the coatings.

It can be assumed that for thin coatings (up to $20 \mu \mathrm{m}$ ) there is a high probability of protective layer formation near a metal surface due to easy penetration of an electrolyte to the growing inner layer of a coating, thus, electrolysis of ${ }^{1} n\left[\mathrm{Si}_{x} \mathrm{O}_{y}\right]^{m-}$ polyanions and electrophoresis of $\mathrm{Co}(\mathrm{OH})_{3}$ should occur more intensively on it. Therefore, the closure of the coating pores in the inner layer take place. On the other hand, PET processing of the thick coatings due to existence of the compact inner layer results in decreasing of microdischarges quantity, thus, leading to higher energy emitting in them. Plasma electrolytic treatment of the inner layer take place, probably, resulting in formation of cobalt

\footnotetext{
${ }^{1}$ the stoichiometric coefficients depend on $\mathrm{pH}$ of electrolytes adjacent to a working electrode and existing in coating pores; their values increase with increase PEO processing duration [39].
} 
orthosilicate at different place of the coatings. Despite partial closure of the pores with cobalt orthosilicate, the grown layer in the thick coatings $(>38 \mu \mathrm{m})$ is not the most protective.

(a)

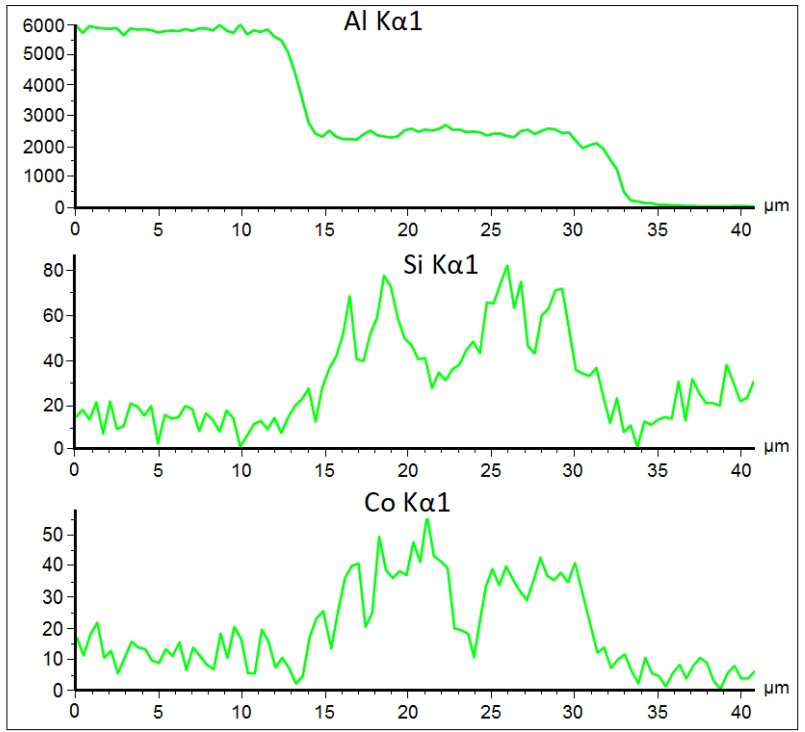

(b)
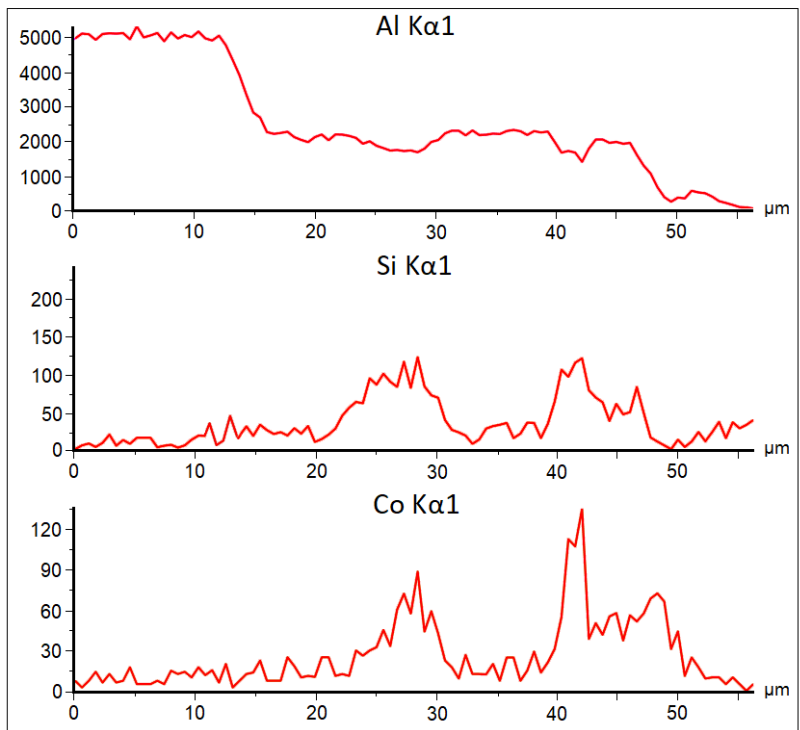

(c)

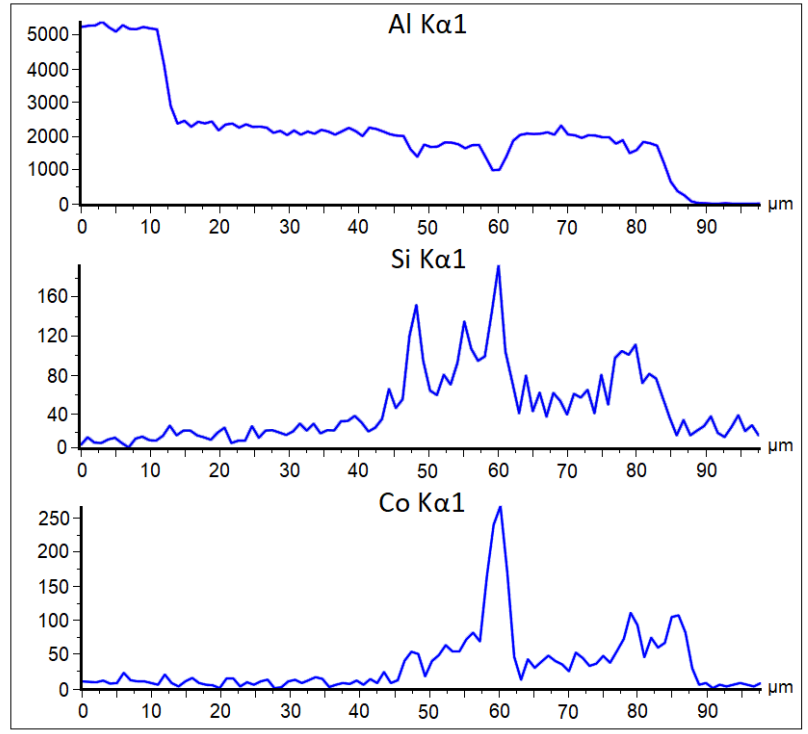

Figure 6. The distribution of elements $\mathrm{Al}, \mathrm{Si}, \mathrm{Co}$ in the black PET coatings; average coating thicknesses are 17 (a), 38 (b) and 70 (c) $\mu \mathrm{m}$.

The proposed mechanism is also proved by the results of corrosion tests of PET coated samples impregnated with mixed inhibitor of SOS and SFF. 
Impact of the mixed corrosion inhibitor of SOS and SFF on anticorrosion properties of PET coated AA2024 alloy
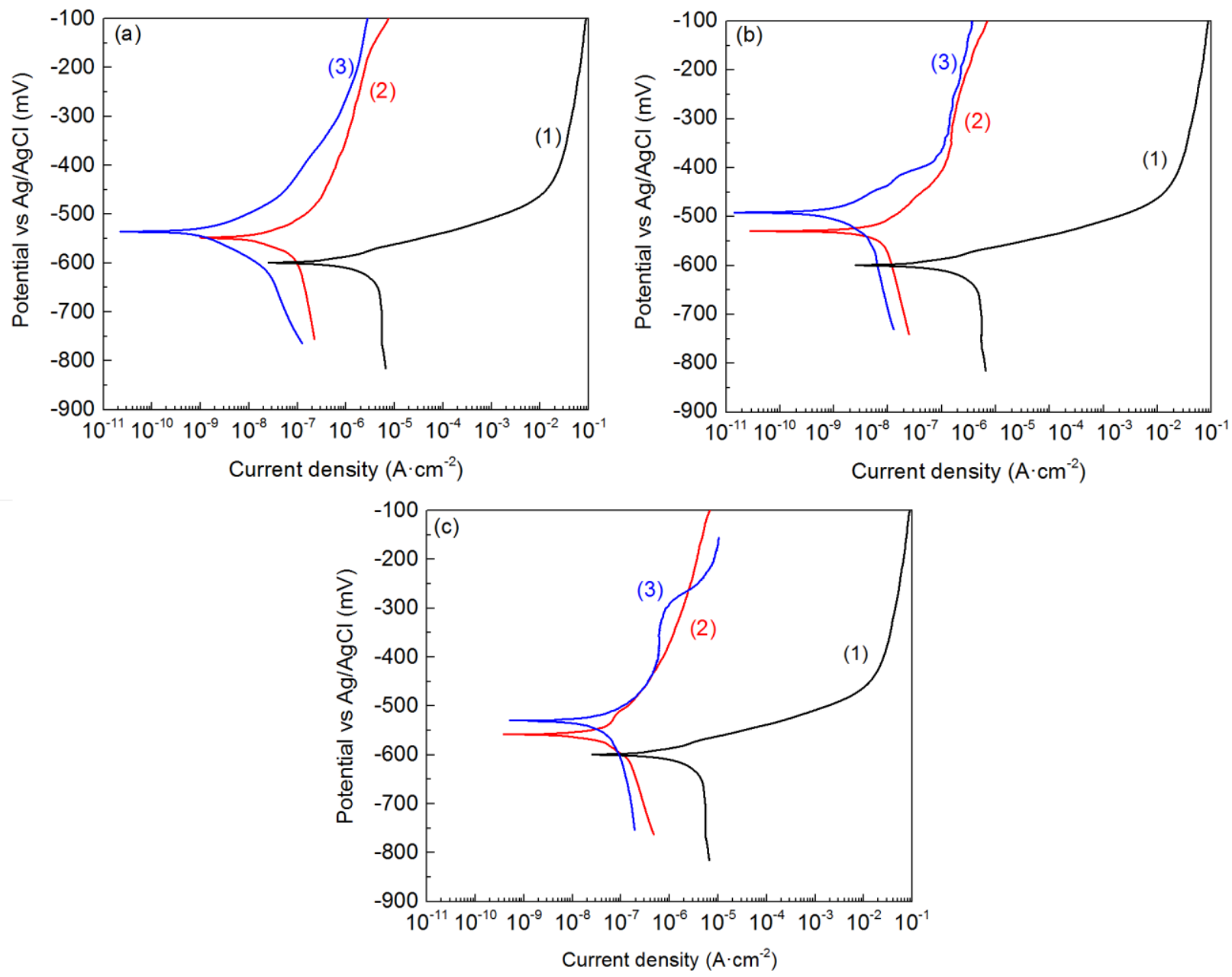

Figure 7. Potentiodynamic polarization curves for the corrosion of AA2024 alloy in 3 wt. \% NaCl aqueous solution without (1) and with PET inhibitor-containing coatings obtained in the base electrolyte (2) and with addition of $1.5 \mathrm{~g} / \mathrm{l} \mathrm{Co}(\mathrm{OH})_{3}(3)$; average coating thicknesses are 17 (a), 38 (b), 70 (c) $\mu \mathrm{m}$.

After treatment in the mixed inhibitor $\left(\sum C_{\text {inh }}=16 \mathrm{mM}, \tau_{\text {treat }}=10 \mathrm{~min}\right)$, samples with the average coating thickness of $17 \mu \mathrm{m}$ show greatest decrease in corrosion current density. Corrosion current density of AA2024 alloy with PET coating (average thickness $17 \mu \mathrm{m}$ ) obtained in the base electrolyte after treatment in the chosen corrosion inhibitor decreases 45.7 times, while for the one obtained in the electrolyte with addition of $1.5 \mathrm{~g} / \mathrm{l} \mathrm{of} \mathrm{Co}(\mathrm{OH})_{3}$, 467.4 times (Table 4). However, impact of inhibitor treatment on black PET coatings is not so highly efficient as for AA2024 alloy PET treated in the base electrolyte. Evidently, the latter is based on high anticorrosion properties of black coatings in comparison with samples PET treated in the base electrolyte. 
Table 4. Corrosion potentials and currents of AA2024 alloy without and with PET inhibitor-containing coatings in 3 wt. $\% \mathrm{NaCl}$ aqueous solution.

\begin{tabular}{c|c|c|c}
\hline $\begin{array}{c}\text { Coating } \\
\text { thickness, } \boldsymbol{\mu m}\end{array}$ & Electrolyte & $\boldsymbol{- V}, \mathbf{m V}$ & $\boldsymbol{i}, \mathbf{A} / \mathbf{c m}^{2}$ \\
\hline 0 & - & 598 & $4.3 \times 10^{-6}$ \\
\hline \multirow{2}{*}{17} & Base & 544 & $9.4 \times 10^{-8}$ \\
\cline { 2 - 4 } & $\begin{array}{c}\text { With addition of } 1.5 \mathrm{~g} / \mathrm{l} \\
\mathrm{Co}(\mathrm{OH})_{3}\end{array}$ & 535 & $9.2 \times 10^{-9}$ \\
\hline \multirow{2}{*}{38} & Base & 528 & $8.7 \times 10^{-8}$ \\
\cline { 2 - 4 } & $\begin{array}{c}\text { With addition of } 1.5 \mathrm{~g} / \mathrm{l} \\
\mathrm{Co}(\mathrm{OH})_{3}\end{array}$ & 493 & $3.4 \times 10^{-8}$ \\
\hline \multirow{2}{*}{70} & Base & 558 & $7.9 \times 10^{-8}$ \\
\cline { 2 - 4 } & $\begin{array}{c}\text { With addition of } 1.5 \mathrm{~g} / 1 \\
\mathrm{Co}(\mathrm{OH})_{3}\end{array}$ & 501 & $6.1 \times 10^{-8}$ \\
\hline
\end{tabular}

Corrosion current densities do not decrease significantly after the inhibition of dense thick PET coatings (average thicknesses are 38,70 $\mu \mathrm{m}$ ) synthesized on AA2024 alloy (Figure 7, Table 4). Impregnation of PET coated AA2024 samples with an average coating thickness of $38 \mu \mathrm{m}$ obtained in the base electrolyte and with the addition of $\mathrm{Co}(\mathrm{OH})_{3}$, in the mixed inhibitor, leads to an additional decrease of corrosion current densities by 2.87 and 2.29 times; for samples with an average thickness of $70 \mu \mathrm{m}$, only by 1.51 and 1.39 times, respectively. Probably, this is due to nanopores existence in the inner layer of dense coatings, the number of which exceeds number of micropores considerably [38]. The inhibitor cannot penetrate into these nanopores.

Thus, the efficiency of corrosion inhibitor depends on accessible open porosity of a coating: the higher open porosity is, the better inhibition performance. Black PET coatings with average thickness of $17 \mu \mathrm{m}$ in combination with the mixed inhibitor of SOS and SFF can be recommended as an effective way for corrosion protection of AA2024 alloy.

\section{Conclusions}

1. It was established that the addition of $1.5 \mathrm{~g} / \mathrm{C} \mathrm{Co}(\mathrm{OH})_{3}$ into an alkaline aqueous solution ( $\mathrm{pH} \sim 12.6$ ), containing $5 \mathrm{~g} / \mathrm{l}$ of technical water glass, results in formation of visually black PET coatings with higher anticorrosion properties.

2. The mechanism of the intensive formation of the inner layer and the closure of the coating horizontal pores on AA2024 alloy during its PET processing was proposed. This mechanism is based on the ignition of nano- and micro-discharges under the outer layer and horizontal pores of the coatings.

3. It was shown that anticorrosion ability of PET coatings with different thicknesses synthesized in the base electrolyte without addition of $1.5 \mathrm{~g} / \mathrm{l}$ of $\mathrm{Co}(\mathrm{OH})_{3}$ into it, is lower 
than the one of the black PET coatings. Probably, it is caused by the formation of cobalt orthosilicate in the black coating pores, which is more fusible in comparison with aluminum and silicon oxides.

4. It was discovered that the black PET coating with an average thickness of $17 \mu \mathrm{m}$ has better anticorrosion ability than the ones of the coatings with average thicknesses of 38 or $70 \mu \mathrm{m}$. Fewer pores of a small diameter in the thick PET coatings are covered with molten $\mathrm{Co}_{2} \mathrm{SiO}_{4}$, this results in a lower corrosion resistance.

5. The efficiency of the mixed inhibitor of SOS and SFF application for increasing the anticorrosion ability of PET coatings on AA2024 alloy has been revealed. Efficiency of the corrosion inhibitor depends on a coating thickness, it decreases with a coating thickness: the thicker a coating is, the lower efficiency of the corrosion inhibitor.

\section{Acknowledgements}

This work was financially supported by the RFBR (Project No. 18-53-76008) in the framework of the ACTICOAT project (Era.Net RUS Plus Call 2017, Project 477).

\section{References}

1. W. McNeill and R. Wick, Effect of various polyvalent metal anion addition to an alkaline magnesium anodizing bath, J. Electrochem. Soc., 1957, 104, no. 6, 356-359. doi: $\underline{10.1149 / 1.2428581}$

2. W. McNeill, The preparation of cadmium niobate by an anodic spark reaction, $J$. Electrochem. Soc., 1958, 105, no. 9, 544-547. doi: 10.1149/1.2428917

3. L.L. Gruss and W. McNeill, Anodic spark reaction products in aluminate, tungstate and silicate solutions, Electrochem. Technol., 1963, 1, 283-287.

4. W. McNeill and L.L. Gruss, Anodic film growth by anion deposition in aluminate, tungstate and phosphate solutions, J. Electrochem. Soc., 1963, 110, no. 8, 853-855. doi: $\underline{10.1149 / 1.2425890}$

5. W. McNeill, L.L. Gruss and D.G. Husted, The anodic synthesis of CdS films, $J$. Electrochem. Soc., 1965, 112, no. 7, 713-715. doi: $10.1149 / 1.2423672$

6. A.N. Mikheev, A.V. Girn, D.V. Orlova, E.V. Vakhteev and T.V. Trushkina, Vliyanie tekhnologicheskikh parametrov na elementnyi sostav mikrodugovogo oksidirovaniya pokrytii na alyuminievykh i titanovykh splavakh (Influence of technological parameters on the elemental composition of MAO coatings on aluminum and titanium alloys), Vestnik SibGAU, 2012, 4, 168-172 (in Russian).

7. J. Schmidt, T. Furche, R. Erdmann, M. Reichert, U. Bayer, P. Kurze, T. Schwarz, J. Schreckenbach, H.J. Kletke, A. Hofmann, M. Heppner, A. Hasse, D. Schmidt and A. Klaus, Black surface layer on light metal, US Patent 5075178, 1991.

8. J. Schmidt, T. Furche, R. Erdmann, M. Reichert, U. Bayer, P. Kurze, T. Schwarz, J. Schreckenbach, H.J. Kletke, A. Hofmann, M. Heppner, A. Hasse and D. Schmidt, 
Electrolyte for the production of black surface layers on light metals, US Patent 5035781, 1991.

9. Agreement of the member state committee on the identification of potassium chromate as a substance of very high concern, According to Articles 57 and 59 of Regulation (EC. 1907/2006 (REACH)), Adopted on 4 June 2010.

10. A.I. Mamaev, P.I. Butyagin, Zh.M. Ramazanova, D.G. Miroshnikov and Yu.Yu. Chekanova, Keramicheskoe pokrytie, podoshva utyuga i sposob polucheniya keramicheskogo pokrytiya na izdeliyakh iz alyuminiya ili ego splavov (Ceramic coating, iron soleplate and a method of obtaining a ceramic coating on products made from aluminum and its alloys), RU Patent 2213166 C2, 2000 (in Russian).

11. T.P. Yarovaya, P.S. Gordienko, V.S. Rudnev and P.M. Nedozorov, Sposob polucheniya opticheski chernykh zashchitnykh pokrytiy na ventil'nykh metallakh (Method of obtaining optically black protective coatings on valve metals), RU Patent 2096534 C1, 1997 (in Russian).

12. A.G. Rakoch, K.S. Melkonyan, A.A. Gladkova, Yu.A. Pustov, V.V. Savva and D.V. Kuznetsov, Osobennosti stroyeniya i formirovaniya dekorativnykh chernykh zashchitnykh pokrytiy na splave D16 metodom plazmenno-elektroliticheskogo oksidirovaniya (Features of the structure as well as the process of decorative black protective coatings formation on duralumin surface by plasma electrolytic oxidation method), Fiz. Khim. Obrab. Mater. (Physics and Chemistry of Materials Treatment), 2015, no. 5, 35-43 (in Russian).

13. A.G. Rakoch, E.P. Monakhova, A.A. Gladkova, C.V. Fan and N.A. Predein, Vliyanie rastvorennykh oksidov dvukhvalentnykh metallov $\mathrm{v}$ pokrytiyakh na osnove oksida alyuminiya na ikh fazovyi sostav i iznosostoikost' (Influence of dissolved oxides of bivalent metals in coatings based on aluminum oxide on their phase composition and wear resistance), Korroz.: Mater., Zashch. (Corros.: Mater., Prot.), 2017, no. 3, 26-34 (in Russian).

14. H. Tang, Q. Sun, T. Xin, C. Yi, Z. Jiang and F. Wang, Influence of $\mathrm{Co}\left(\mathrm{CH}_{3} \mathrm{COO}\right)_{2}$ concentration on thermal emissivity of coatings formed on titanium alloy by micro-arc oxidation, Curr. Appl. Phys., 2012, 12, 284-290. doi: 10.1016/j.cap.2011.06.023

15. P. Wang, Z.Y. Gong, H.L. Li, Q.G. Yang, W.J. Cao, J Hu, J. Pu, X.Y. Guo and D. Xiang, Effect of $\mathrm{CoSO}_{4}$ on the characteristics of micro-arc oxidation coatings, Surf. Eng., 2020, 36, no. 2, 216-224. doi: 10.1080/02670844.2019.1650468

16. J. Hu, P. Wang, D.D. Liao, X.Y. Sun, Z.Y. Gong, J.W. Liu, D. Xiong, D. Xiang, X.T. Zu and X.W. Wei, Effects of cobalt (II) sulfate addition on structure and corrosion resistance of alloy micro-arc oxidation coating on the ZL108 aluminum, Int. J. Electrochem. Sci., 2020, 15, 4978-4987. doi: 10.20964/2020.06.78

17. A.G. Rakoch, A.A. Gladkova, L. Zayar and D.M. Strekalina, The evidence of cathodic micro-discharges during plasma electrolytic oxidation of light metallic alloys and microdischarge intensity depending on $\mathrm{pH}$ of the electrolyte, Surf. Coat. Technol., 2015, 269, 138-144. doi: $\underline{10.1016 / j . s u r f c o a t .2015 .02 .026}$ 
18. A.G. Rakoch, A.V. Dub and A.A. Gladkova, Anodirovanie legkikh splavov pri razlichnykh elektricheskikh rezhimakh. Plazmenno-elektroliticheskaya nanotekhnologiya (Anodizing of light alloys in various electric modes. Plasma-electrolytic nanotechnology), Moscow, Staraya Basmannaya Publishing, 2012, 495 pp. (in Russian).

19. A.G. Rakoch, A.A. Gladkova and A.V. Dub, Plazmenno-elektroliticheskaya obrabotka aluminievykh $i$ titanovykh splavov (Plasma-electrolytic treatment of aluminum and titanium alloys), Moscow, MISiS Publishing House, 2017, p. 160 (in Russian).

20. I.V. Suminov, A.V. Epelfeld, V.B. Ludin, B.L. Krit and A.M. Borisov, Mikrodugovoye oksidirovaniye: teoriya, tekhnologiya, oborudovaniye (Microarc oxidation: theory, technology, equipments), Moscow, Ekomet Publ., 2005, p. 368 (in Russian).

21. S.V. Lamaka, M.L. Zheludkevich, K.A. Yasakau, M.F. Montemor and M.G.S. Ferreira, High effective organic corrosion inhibitors for 2024 aluminium alloy, Electrochim. Acta, 2007, 52, 7231-7247. doi: 10.1016/j.electacta.2007.05.058

22. S. Marcelin and N. Pebere, Synergistic effect between 8-hydroxyquinoline and benzotriazole for the corrosion protection of 2024 aluminium alloy: a local electrochemical impedance approach, Corros. Sci., 2015, 101, 66-74. doi: 10.1016/j.corsci.2015.09.002

23. G. Boiser, N. Portail and N. Pebere, Corrosion inhibition of 2024 aluminium alloy by sodium decanoate, Electrochim. Acta, 2010, 55, 6182-6189. doi: 10.1016/j.electacta.2009.10.080

24. Yu.I. Kuznetsov, Organic inhibitors of corrosion of metals, 1996, New York, Plenum Press, 283.

25. Yu.M.Zimina, Yu.A. Kuzenkov and S.V. Oleynik, Zashchitnye konversionnye pokrytiya IFKhANAL na alyuminiyevykh splavakh (IFKhANAL protective conversion coatings on aluminum alloys), Korroz.: Mater., Zashch. (Corros.: Mater., Prot.), 2010, no. 7, 44-48 (in Russian).

26. S.V. Oleinik, V.S. Rudnev, Yu.A. Kuzenkov, T.P. Yarovaya, L.F. Trubetskaya and P.M. Nedozorov, Modifitsirovanie PEO-pokrytii na alyuminiyevykh splavakh ingibitorami korrozii (Modification of PEO coatings on aluminum alloys with corrosion inhibitors), Korroz.: Mater., Zashch. (Corros.: Mater., Prot.), 2012, no. 11, 36-41 (in Russian).

27. A.M. Semiletov, A.A Chirkunov and Yu.I. Kuznetsov, Zashchita splava D16 ot korrozii v neytral'nykh vodnykh rastvorakh i agressivnoi atmosfere organicheskimi ingibitorami (Protection of D16 alloy against corrosion in neutral aqueous solutions and in a corrosive atmosphere using organic inhibitors), Korroz.: Mater., Zashch. (Corros.: Mater., Prot.), 2019, no. 7, 34-41 (in Russian). doi:10.31044/1813-7016-2019-0-7-34-41

28. M. Stern and A.L. Geary, Electrochemical polarization: i. A theoretical analysis of the shape of polarization curves, J. Electrochem. Soc., 1957, 104, 56-63.

29. Fiziko-khimicheskiye svoystva okislov. Spravochnik (Physicochemical properties of oxides. Handbook), Ed.: G.V. Samsonov, 1978, Moscow, Metallurgiya, 472 (in Russian). 
30. A.I. Sonova and O.P. Terleeva, Morfologiya, struktura i fazovyi sostav mikroplazmennykh pokrytii, sformirovannykh na splave $\mathrm{Al}-\mathrm{Cu}-\mathrm{Mg}$ (Morphology, structure and phase composition of microplasma coatings formed on an $\mathrm{Al}-\mathrm{Cu}-\mathrm{Mg}$ alloy), Zashch. Met. (Prot. Met.), 2008, 44, no. 1, 72-83 (in Russian).

31. A.G. Rakoch, I.V. Bardin, V.L. Kovalev and T.G. Avanesyan, Mikrodugovoe oksidirovaniye legkikh konstruktsionnykh splavov. Chast' 1. Osnovnye predstavleniya o mikrodugovom oksidirovanii legkikh konstruktsionnykh splavov (Microarc oxidation of light structural alloys: Part 1. Main concepts on microarc oxidation of light structural alloys), Izv. vuzov. Poroshk. metallurgiya i funkts. Pokrytiya. (Powder Metallurgy and Functional Coatings), no. 2, 58-62 (in Russian).

32. A.G. Rakoch, V.V. Khokhlov, V.A. Bautin, N.A. Lebedeva, Yu.V. Magurova and I.V. Bardin, Model'nye predstavleniya o mekhanizme mikrodugovogo oksidirovaniya metallicheskikh materialov i upravlenie etim protsessom (Model concepts on the mechanism of microarc oxidation of metal materials and the control over this process), Zashch. Met. (Prot. Met.), 2006, 42, no. 2, 173-184.

33. A.L. Yerokhin, L.O. Snizhko, N.L. Gurevina, A. Leyland, A. Pilkington and A. Matthews, Discharge characterization in plasma electrolytic oxidation of aluminium, J. Phys. D: Appl. Phys., 36, 2110-2120. doi: 10.1088/0022-3727/36/17/314

34. V.V. Bakovets, O.V. Polyakov and I.V. Dolgovesova, Plazmenno-elektroliticheskaya anodnaya obrabotka metallov (Plasma electrolytic anodic treatment of metals), Nauka, Sibirskoe otdelenie, Novosibirsk, 1991, p. 168 (in Russian).

35. C.S. Dunleavy, I.O. Golosnoy, J.A. Curran and T.W. Clyne, Characterisation of discharge events during plasma electrolytic oxidation, Surf. Coat. Technol., 2009, 203, 3410-3419. doi: 10.1016/j.surfcoat.2009.05.004

36. A.N. Efimov, I.P. Belorukova, I.V. Vasilkova and V.P. Chechev, Svoistva neorganicheskikh soedinenii. Spravochnik (Properties of inorganic compounds. Handbook), Leningrad, Khimiya, 1983, p. 392 (in Russian).

37. Diagrammy sostoyaniya dvoynykh metallicheskikh system. Spravochnik (State diagrams of binary metal systems. Handbook), Ed.: N.P. Lyakishev, Moscow, Mashinostroeniye, 1996, vol. 1, p. 992 (in Russian).

38. J.A. Curran and T.W. Clyne, Porosity in plasma electrolytic oxide coatings, Acta Mater., 2006, 54, 1985-1993. doi: 10.1016/j.actamat.2005.12.029

39. V.I. Chernenko, L.A. Snezhko and I.I. Papanova, Polucheniye pokrytii anodnoiskrovym elektrolizom (Production of coatings by anodic spark electrolysis), Leningrad, Khimiya, 1991, p. 128 (in Russian). 